\title{
Legitimasi Pemilihan Umum di Indonesia Tahun 2019
}

\author{
Untung Sri Hardjanto \\ Fakultas Hukum, Universitas Diponegoro \\ untungsri@gmail.com
}

\begin{abstract}
The article aims to find out the legitimacy of the general elections in Indonesia in 2019, especially related to the future implementation of the basic constitution for holding the 2019 general election. Research is normative legal research based on the statutory approach. the results of the study indicate that legitimacy is the recognition and support of the community towards the winner of the election to then form a state government. So that legitimacy is needed for political stability and the possibility of social change and opening opportunities to expand fields in order to improve welfare. For Indonesia, the 2019 Election will receive formalprocedural legitimacy from anyone considering the existence of institutions that carry out the implementation of elections based on the principle of overflow. Whereas the legitimacy that is based on personal characteristics will only be a comparison and directing, leading to the voting of the people, will not affect the government formed given the existence of peaceful and democratic election pacts and the media that has arrived in the regions.
\end{abstract}

Keywords: Legitimacy, Constitution, General Elections, Jurdil and Luber

\begin{abstract}
Abstrak
Artikel bertujuan untuk mengetahui legitimasi pemilihan umum di Indonesia tahun 2019, khususnya terkait dengan masa depan pelaksanaan dasar konstitusi penyelenggaraan pemilihan umum 2019. Penelitian merupakan penelitian hukum normatif yang berdasarkan pada pendekatan statutory approach. hasil penelitian menjukkan bahwa legitimasi merupakan pengakuan dan dukungan dari masyarakat terhadap pemenang pemilu untuk kemudian membentuk pemerintahan negara. Sehingga legitimasi diperlukan untuk kesetabilan politik dan kemungkinan terjadinya perubahan sosial serta membuka kesempatan memperluas bidangbidang dalam rangka peningkatana kesejahteraan. Untuk Indonesia, Pemilu Tahun 2019 akan mendapat legitimasi formal-prosedural dari siapapun mengingat adanya lemabaga negara yang menjalankan penyelenggaraan pemilu berdasar pada asas luber jurdil. Sedangkan legitimasi yang mendasarkan pada ciri pribadi hanya akan menjadi pembanding dan mengarahkan, menggiring menuju pemberian suara masyarakat, tidak akan berpengaruh pada pemearintahan yang terbentuk mengingat adanya pakta pemilu damai dan demokratis serta mas media yang sudah sampai kedaerah.
\end{abstract}

Kata Kunci: Legitimasi, Konstitusi, Pemilihan Umum, Jurdil dan Luber 


\section{A. Pendahuluan}

Pemilihan Umum (Pemilu) merupakan sarana yang sangat penting dalam menjalankan demokrasi. Melalui pemilihan umum rakyat menyalurkan aspirasinya untuk menunjuk pemimpinnya dan memilih wakilnya guna merumuskan apa yang menjadi kehendak rakyat yang akan dirumuskan menjadi kehendak negara.

Pada system politik (Penyelenggaraan Pemerintahan Negara), pemilihan umum menurut Jimly As memiliki 4 (empat) tujuan: ${ }^{1}$

a. Untuk memungkinkan terjadinya peralihan kepemimpinan pemerintahan secara tertib dan damai;

b. Untuk memungkinkan terjadinya pergantian pejabat yang akan mewakili kepentingan rakyat di lembaga perwakilan;

c. Untuk melaksanakan prinsip kedaulatan rakyat, dan

d. Untuk melaksanakan prinsip hak-hak asasi warga negara

Dengan demikian dapat dikatakan bahwa Pemilihan Umum tidak saja penting bagi warga negara, tetapi juga bagi pejabat penyelenggara pemerintahan negara.

Bagi penyelenggara pemerintahan negara yang dipilih secara jujur melalui pemilihan umum berarti bahwa pemerintahan itu mendapat dukungan sebenarnya dari rakyat. Sebaliknya jika pemerintahan itu terbentuk dari hasil pemilu yang tidak jujur maka dukungan rakyat kepada pemerintahanya bersifat semu.

Melaluipemilihanumumtergambar pula aspirasirakyat yang sesungguhnya sebagai pemilik kedaulatan dalam sebuah negara. Karena itu dapat menggambarkan seberapa besartingkat dukungan dan kepercayaan rakyat kepada pemerintah. Harian Kompas 5 Januari 2019, menurunkan tulisan Jaga Legitimasi Pemilu 2019, dikatakan pemilihan umum di Indonesia tahun 2019 yang merupakan pemilihan umum serentak legislative dan eksekutif akan menentukan kualitas dan masa depan demokrasi di Indonesia. Munculnya sejumlah polemik dan informasi tidak benar terkait pemilu, berpotensi mengancam legitimasi pemilu.Ini akan mempengaruhi legitimasi peierintahan Negara Kesatuan Republik Indonesia.

Upaya menjaga legitimasi pemilihan umum semakin mendesak. Adanya polemik sekitar daftar pemilh,kotak suara, adanya surat suara yang sudah tertoblos.Belum lagi

\footnotetext{
${ }^{1}$ Jimly Asshidiqie. 2006. Pengantar Hukum Tata Negara Jilid II. Konstitusi Press: Jakarta. Hlm: 174.
} 
adanya yang memepersoalkan personal calon presiden dan wakil preiden, terkait ideologi, suku,agama ,kekayaan sampai gestur tubuh.

Terkait hal itu ,komisioner KPU Wahyu Setiawan menyatakan melihat adanya gejala delegitimasi pemilu dengan delegitimasi penyelenggara pemilu.Secara terpisah anggota DPR Bambang Susatyo menuturkan ,meski kabar tentang surat suarayang sudah tertoblos adalah berita bohong, KPU dan Bawaslu tetap harus mengecek agar pemilu berjalan adil dan jujur.

Guru Besar Henry Subianto mengatakan, penyebaran hoaks di media sosial telah menjadi bagian dari permainan politik. Sehingga menjadi permasalahan,mengapa memerlukan legitimasi, pemilu yang bagaimana yang dapat menjadi dasar pembentukan pemerintahan yang baru ,khususnya pemilihan umum di Indonesia Tahun 2019 ini ?

\section{B. Pembahasan}

\section{Kekuasaan, Kewenangan, danLegitimasi}

Menurut Ramlan Surbhakti, kewenangan adalah kekuasaan. Namun, kekuasaan tidak selalu berupa kewenangan. Kewenangan merupakan kekuasaan yang memiliki keabsahan (legitimate power) sedangkan kekuasaan tidak selalu memiliki keabsahan.

Kewenangan adalah hak moral bagi kekuasaan untuk membuat dan melaksanakan keputusan politik (memerintah). Sumber kewenangan untuk memerintah menurut Andrain adalah berasal dari tradisi, Tuhan, kualitas pribadi, peraturan perundangundangan, instrumental. ${ }^{2}$

Masyarakatdapatmemberikanpengakuandandukungankepadapemerintahatasdasarl egitimasitradisional, legitimasi ideology, legitimasikualitaspribadi, legitimasi procedural, danlegitimasi instrumental. ${ }^{3}$ Struktur masyarakat yang kompleks maka tipe kewenangan yang digunakan kurang lebih cenderung bersifat prosedural,sedangkan masyarakat yang masih sederhana cenderung menggunakan tipe kewenangan substansial.

\section{LegitimasiPemilihan Presiden}

${ }^{2}$ Ramlan Surbakti. 2006. Memahami Ilmu Politik. Grasindo: Jakarta. Hlm: 85-86.

${ }^{3}$ ibid 
Jabatan Presiden dalam sebuah Negara merupakan jabatan yang prestise, karena dalam sebuah Negara Presiden adalah kepala Negara, kepala pemerintahan yang memiliki sejumlah kewenangan dalam penyelenggaraan kehidupan negara. ${ }^{4}$ Dengan demikian jabatan Presiden memerlukan (legitimate power) keabsahan. Sumber kewenangan dari calon Presiden adalah kewenangan yang bersifat prosedural dan kewenangan yang bersifat substansial. ${ }^{5}$

Menurut Max Weber ,kewenangan yang bersifat procedural adalah hak memerintah berdasarkan peraturan perundang-undangan yang bersifat tertulis maupun tak tertulis. Kewenangan bersifat substansial ialah hak memerintah berdasarkan pada faktor-faktor yang melekat pada diri pemimpin seperti tradisi, sakral, kualitas pribadi dan instrumental. ${ }^{6}$ Pada pemilihan presiden faktor pribadi calon yang bersiafat substansial akan lebih menonjol menuju sesuatu yang bersifat prosedural.

\section{LegitimasiPemilu Legislatf}

Pemilihan umum itu penting bagi para pejabat dan wakil rakyat sendiri, untuk mengukur tingkat dukungan dan kepercayaan masyarakat kepada pemerintah. Pemilu haruslah dilaksanakan secara jujur sehingga dapat dilihat legitimasi yang sebenarnya. Untuk proses pemilihan umum legislatif kebsahan lebih kearah akan tergantung dari penyelenggaraan pemilihan umum sendiri yang bersiaft prosedural. ${ }^{7}$ ( Jimly A, 2006, hal.32 ). Tidak adanya pelanggaran terhadap ketentuan pemilu ,terselesaikannya sengketa pemilu dan dijalankannya asas seperti umum, langsung, bebas dan rahasia sertaa jujur dan adil dan hasil akhir pemilu. Tentu tidak terlepas faktor yang melekat pada diri calon anggota dewan.Sehingga menuntut keoptimalan Penyelenggara Pemilu ,pemerintah,dan peserta pemilu, masyarakat dalam penyelenggaraan pemilihan umum.

\section{Legitimasi Pemilihan Umum Di Indonesia Tahun 2019.}

\footnotetext{
${ }^{4}$ Jimly Asshidiqie. 2006. Pengantar Hukum Tata Negara. Konstitusi Press: Jakarta. Hlm: 59.

${ }^{5}$ Frans Magnis Suseno. 1998. Etika Politik. Gramedia: Jakarta. Hlm: 65.

${ }^{6}$ Op. Cit. Ramlan Surbakti. Hlm: 97.

${ }^{7}$ Op. Cit. Jimly Asshidiqie. Hlm: 32.
} 
Pemilihan Umum Di Indonesia Tahun 2019 yang berdasar UU No 7 Tahun 2017, merupakan pemilihan umum serentak anggota DPD, anggot DPR, anggota DPRD dan Preseden dan Wakil Presiden R I tahun 2019. Pemilihan Umum dimaksudkan untuk menjalankan demokrasi , memperkuat sistem ketatanegaraan danmemberikan kepastian hukum.Untuk itu penyelenggaraan pemilihan umum di Indonesia harus berdasar pada asas langsung,umum bebas ,rahasia serta jujur dan adil serta harus memenuhi asas asas mandiri,jujur,adil,berkepastianhukum,tertib,terbuka,proporsional,profesional,akuntabel, efektif dan efisien.

Ketentuan-kentuan dalam UU No7 Tahun 2017 memberikan tafsiran bahwa pemilihan umum lembaga legislatif akan selesai apabila tidak ada lagi sengketa mengenai hasil akhir pemilu,berupa angka angka perhitungan yang sudah disetujui oleh para pihak terkait sebagai peserta pemilu. Dan sebelumnya sudah tidak ada pelanggaran pemilu maupun tindak pidana yang masih belum selesai proses perkaranya.

Berdasarkan pada dasar hukum dan pemikiran diatas maka pemilihan umum lembaga legislatif sah dan diakui setelah selesainya prosedure penyelengaraan pemilu. Pemilihan umum mendapatkan legitimasinya secara formal-prosedural berdasar pada ketentuan peraturan, diakui oleh pemerintah ,para pihak peserta pemilu dan rakyat yang telah menyalurkan aspirasinya

Pemberian legitimasi substansial mayarakat kepada pemerintahan/pemimpin yang mendasarkan pada pribadi pemimpin berupa kualitas, tradisi, kesakralan dan instrumental hanya menjadi pembanding untuk mengarahkan pada perolehan suara para caolon anggota DPR, DPRD, DPD.

Berbeda dengan legitimasi pada pemilihan Presiden dan Wapres Tahun 2019 ini,jabatan Presiden adalah jabatan paling tinggi dalam pemerintahan sebuah negara . Menurut Ferero,pengakuan dan dukungan masyarakat akan sangat dipengaruhioleh legitimasi tradisional, ideologi, kualitas pribadi, prosedural dan legitimasi instrumental. ${ }^{8}$

Seperti halnya, kubu Prabowo mempermaslahkan ideologi Jokowi, keagamaann Jokowi , kualitas calon Presiden dll. Jadi ciri personal sepeti ideologi,kualitas dan tradisi akan sangat mementukan keberhasilan dalam menentukan legitimasi prosdural dan instrumen yang hanya dianggap sarana mencapai kemenangan untuk mendapat

\footnotetext{
${ }^{8}$ Op. Cit. Ramlan Surbakti. Hlm: 97.
} 
kekuasaan. Sedangkan kubu Jokowi selalu mendasarkan survei angka-angka kemenangan dibarengi dengan rencana program sebagai instrumen mensejahterakan rakyat.

Oleh karena itu, mendasarkan pada ciri masyarakat Indonesia yang terbelah menjadi suku bangsa suku bangsa secara horizontal yang berbeda penangkapannya dalam memberi legitimasi formal dan pribadi maupun secara vertikal tebelah kota dan desa sehingga terjadi perbedaan memberi legitimasi formal maupun pribadi. Maka mungkin terjadi kecenderungan legitimasi prosedural di kota-kota yang didukung latar belakang kualitas pribadi dan programnya.Dan berhadapan dengan kecenderungan melihat kemampuan dan ciri pribadi yang akan mengarahkan hasil akhir sebagai keinginan masyarakat tradisional dan pedesaan

\section{Penutup}

Berdasarkan pada uraian diatas maka dapat disimpulkan bahwa legitimasi merupakan pengakuan dan dukungan dari masyarakat terhadap pemenang pemilu untuk kemudian membentuk pemerintahan negara. Sehingga legitimasi diperlukan untuk kesetabilan politik dan kemungkinan terjadinya perubahan sosial serta membuka kesempatan memperluas bidang-bidang dalam rangka peningkatana kesejahteraan.

Untuk Indonesia, Pemilu Tahun 2019 akan mendapat legitimasi formal-prosedural dari siapapun mengingat adanya lemabaga negara yang menjalankan penyelenggaraan pemilu berdasar pada asas luber jurdil. Sedangkan legitimasi yang mendasarkan pada ciri pribadi hanya akan menjadi pembanding dan mengarahkan, menggiring menuju pemberian suara masyarakat, tidak akan berpengaruh pada pemearintahan yang terbentuk mengingat adanya pakta pemilu damai dan demokratis serta mas media yang sudah sampai kedaerah.

\section{Daftar Pustaka}

Agus Pramono, Potret Elite Politik: Yang Loyo Dan Harapan Masa Depan, Lemhanas, Jakarta, 2004.

Alwi Wahyudi, Hukum Tata Negara Indonesia : Dalam Perspektif Pancasila dan Reformasi,Pustaka Pelajar , Jakarta, 2012.

-Frans Magnis Suseno, Etika Politik, Gramedia, Jakarta, 1988 
Jimly Asshiddiqi, Pengantar Ilmun Hukum Tata Negara Jilid II, Konstitusi Press, Jakarta, 2006.

Kuntowijoyo, Demokrasi dan Budaya Demokrasi, Yayasan Bentang, Yogyakarta,1994. Miriam Budiardjo, Dasar-Dasar Ilmu Politik, PT.Gramedia, Jakarta, 2003. Ramlan Surbakti, Memahami Ilmu Politik, PT. Grasindo, Jakarta, 1992. Setya Basri, Pengantar Ilmu Politik, Indie Book Corner, Yogyakarta, 2011. Genesis Learning, Undang Undang No,17 Tahun 2017, 2017 